\title{
Insurance market density and economic growth in Eurozone countries: the granger causality approach
}

Rudra P. Pradhan ${ }^{*}$, Saurav Dash, Rana Pratap Maradana², Manju Jayakumar ${ }^{1}$ and Kunal Gaurav ${ }^{1}$

* Correspondence:
rudrap@vgsom.iitkgp.ernet.in
${ }^{1}$ Vinod Gupta School of
Management, Indian Institute of
Technology, Kharagpur 721302,
India
Full list of author information is
available at the end of the article

\section{Springer Open}

\begin{abstract}
Background: This study examines the relationship between insurance market density (IMD) and economic growth.

Methods: We employed Granger causality technique in 19 Eurozone countries for the period 1980-2014. We use three different indicators of IMD, namely life insurance density, non-life insurance density, and total insurance density. We particularly emphasize on whether Granger causality runs between IMD and economic growth both ways, one way, or not at all.

Results: Our empirical result recognizes the presence of both unidirectional and bidirectional causality between insurance market density and economic growth. However, these results are mostly non-uniform across Eurozone countries.

Conclusions: This study holds important policy implications- economic policies should recognize the differences in the insurance market density and economic growth in order to maintain sustainable economic growth in the Eurozone.
\end{abstract}

Keywords: Insurance market density, Economic growth, Granger causality, Eurozone countries

JEL code: $\mathrm{L} 96, \mathrm{O} 32, \mathrm{O} 33, \mathrm{O} 43$

\section{Research highlights for review}

- This study examines the causality between insurance market density (IMD) and economic growth.

- We use 19 Eurozone countries between 1980 and 2014.

- The analysis has been done at individual country level and at Eurozone panel level.

- The study finds an evidence of Granger causality between IMD and economic growth.

- Results in the short run are mostly non-uniform with a few exceptions.

\section{Background}

Theoretical studies and empirical evidences have revealed that countries with welldeveloped financial systems experience faster and more stable long-run economic

(c) The Author(s). 2017 Open Access This article is distributed under the terms of the Creative Commons Attribution 4.0 International License (http://creativecommons.org/licenses/by/4.0/), which permits unrestricted use, distribution, and reproduction in any medium, provided you give appropriate credit to the original author(s) and the source, provide a link to the Creative Commons license, and indicate if changes were made. 
growth. Normally, a well-built financial market ${ }^{1}$ has a significant positive impact on total factor productivity, which translates into high long-run economic growth (see, inter alia, Haiss and Sumegi, 2008; King and Levine, 1993; Levine and Zervos, 1998; Levine et al., 2000). This holds true for all the sub-sectors of financial markets, such as banking sector, stock market, and insurance market. In this paper, we primarily focus on the relationship between insurance market and economic growth. The motivation for this study is based on two typical reasons. First, the coverage of insurance sector has gained less attention in the finance-growth literature, particularly in comparison to both banking sector and stock markets (see, inter alia, Lee et al., 2013a, 2013b). Second, with the process of financial liberalization and integration, we have witnessed an increasingly rapid growth in the insurance market activity during last few years, which raises the question of 'whether insurance market activity promotes economic growth.' This adds to the empirical evidence on resolving the controversial issue between insurance market development and economic growth (see, inter alia, Boon, 2005; Chang et al., 2014).

The relationship between insurance market activities ${ }^{2}$ and economic growth has been broadly discussed in extant literature. ${ }^{3}$ Most of these studies have argued that economic growth is characteristically determined by insurance market activities, with sufficient evidence presented to policymakers to this effect (see, inter alia, Arena 2006; Beck and Webb 2003; Chen et al. 2013; Lee et al. 2012; Hussels et al. 2005). However, in extant literature, the link between insurance market activities and economic growth has not been fully recognized, and most empirical results vary according to data and econometric tools (see, inter alia, Lee et al. 2013a, 2013b; Outreville 2013). There is no universally held view of the nature of causality between insurance market activities and economic growth (see, inter alia, Pradhan et al. 2017; Alhassan and Fiador 2014; Chang et al. 2014; Kugler and Ofoghi 2005; Ward and Zurbruegg 2000). Therefore, we investigate the causal nexus between the two in order to ascertain the actual fact; that is, "How do insurance market activities cause economic growth?" The focus of this study is on Eurozone ${ }^{4}$ countries during the period of 1980-2014.

The remaining paper is outlined as follows. Insurance market activities and economic growth: The theoretical basis presents the theoretical basis of insurance market activities to growth. An outline of insurance market density in the eurozone countries outlines the trend of insurance market density. Empirical strategy deliberates the empirical strategy. Empirical results and discussion presents the empirical results and discussion thereof. Finally, we conclude in Conclusion.

\section{Insurance market activities and economic growth: The theoretical basis}

Like other financial services, such as banking and stock market activities, insurance market activities play a key role in economic growth (see, inter alia, Chang et al. 2014; Ghosh 2013; Garcia 2012; Webb et al. 2005a, 2005b; Lee et al. 2012; Adams et al. 2009; Li et al. 2007; Webb et al. 2005a, 2005b; Outreville 1996) Insurance market activities serve a number of valuable economic functions that are largely distinct from other types of financial intermediaries, such as banking and stock market activities. The insurance market activities- both as a provider of risk transfer and indemnification and as an institutional investor- may contribute to economic growth in the following ways: promoting financial stability, facilitating trade and commerce, 
mobilizing domestic savings, allowing different risks to be managed more efficiently, encouraging the accumulation of new capital, fostering a more efficient allocation of domestic capital, and helping to reduce or mitigate losses (see, inter alia, Pradhan et al. 2015a, 2015b; Liu et al. 2014; Lee et al. 2013a, 2013b; Billio et al. 2012; Guochen and Wei 2012; Haiss and Sumegi 2008; Skipper and Kwon 2007; Kugler and Ofoghi 2005; Ward and Zurbruegg 2000). Additionally, there may be different effects on economic growth from life and non-life insurance market activities given that these two types of insurance market activities protect the households and corporations from different kind of risks that affect the economic activity in different ways. Additionally, life insurance companies facilitate long-term investment, rather than short-term investment, as is the case of non-life insurance companies (see, inter alia, Arena 2008; Brainard 2008).

The degree to which insurance market activities are pervasive in a country is believed to be largely a function of four factors. First, the affordability ${ }^{5}$ of insurance; second, the amount of regulation imposed on the insurance industry by the host government; third, the amount of risk and uncertainty that the people in the society perceive in their lives; and fourth, the degree to which these individuals want to minimize these perceived risks by purchasing insurance rather than relying on the other mechanisms to hedge risks (see, inter alia, Pradhan et al. 2017; Lee et al. 2013a, 2013b; Park et al. 2002; Soo 1996).

At the empirical level, a large section of finance-growth work assesses the impact of the banking sector on economic growth. It shows that the banking sector development contributes to economic growth (see, inter alia, King and Levine 1993), and that there is a positive causal relationship between the two (see, inter alia, Levine 1999; Levine et al. 2000). Similarly, the impact of stock market on economic growth has been studied extensively, justifying the belief that stock market development contributes to economic growth (see, inter alia, Beck and Levine 2004; Caporale et al. 2004; Kar et al. 2011; Levine and Zervos 1998; Arena 2008). Nevertheless, the impact of the insurance market on economic growth has not been studied as extensively as the impacts of the banking sector and stock market. ${ }^{6}$ In this context, our main task is to address the following. First, we examine the existence of cointegration between insurance market activities and economic growth; second, we observe the presence of long-run and short-run direction of causality between the two; and third, we distinguish the particular effects $^{7}$ of life and non-life insurance activities on economic growth.

The literature indicates insurance market activities contribute to economic growth to a great extent (see, inter alia, Chen et al. 2012; Adams et al. 2009; Kugler and Ofoghi 2005). However, it is possible that insurance market activities are also equally exaggerated by economic growth. This means, in practice, insurance market activities and economic growth can Granger cause each other, and hence, there is a prospect of feedback relationship between the two. Overall, there are four possible hypotheses to signify the Granger causal relationship between insurance market activities and economic growth (Pradhan et al. 2017; Alhassan and Fiador 2014; Ward and Zurbruegg 2000).

First, the supply-leading hypothesis (SLH), which posits that insurance market activities are a necessary pre-condition to economic growth. Here, the Granger causality runs from insurance market activities to economic growth. The studies supporting SLH are Alhassan and Biekpe (2016), Pradhan et al. (2017, 2015), Alhassan and Fiador 
(2014), Chang et al. (2014), Lee et al. (2013a, 2013b), Guochen and Wei (2012), Lee (2011), Adams et al. (2009), Kugler and Ofoghi (2005), and Boon (2005).

Second, the demand-following hypothesis ( $D F H$ ), which posits that Granger causality runs from economic growth to insurance market activities. The studies supporting DFH are Alhassan and Biekpe (2016), Pradhan et al. (2015a, 2015b), Chang et al. (2014), Ching et al. (2010), Guochen and Wei (2012), Lee (2011), Kugler and Ofoghi (2005), Beck and Webb (2003), and Ward and Zurbruegg (2000).

Third, the feedback hypothesis (FBH), which posits that economic growth and insurance market activities Granger cause each other. The studies supporting $\mathrm{FBH}$ are Alhassan and Biekpe (2016), Chang et al. (2014), Pradhan et al. (2014, 2015a, 2015b), Guochen and Wei (2012), Kugler and Ofoghi (2005), Ward and Zurbruegg (2000), and Beck and Webb (2003).

Fourth, the neutrality hypothesis $(N L H)$, which posits that economic growth and insurance market activities do not Granger cause each other. The studies supporting NLH are Pradhan et al. (2015a, 2015b), Akinlo (2013), Chang et al. (2014), Chau et al. (2013), Guochen and Wei (2012), and Nejad and Kermani (2012).

Table 8 presents a brief summary of the relationship between insurance market activities and economic growth (see Appendix A). The aim of our study is to validate these four claims in the 19 Eurozone countries. This kind of analysis has received less attention in the literature. This study adds to the scant literature on the insurancegrowth nexus by finding an answer to the question, "Are insurance market activities in Eurozone countries "supply-leading," "demand-following," or "feedback?"”

\section{An outline of insurance market density in the Eurozone countries}

As emphasized above, insurance market activities and economic growth are broadly inter-related, in the process of economic development (Pradhan et al., 2014). There are two diverse ways to address the relationship between insurance market activities and economic growth. First, the regional disparity between insurance market activities and economic growth; and second, the causal relationship between the two. This paper deals with both the issues for the 19 Eurozone countries during the period from 1980 to 2014.

This section discusses the brief profile of Eurozone countries (see Appendix B), an outline of insurance market activities in these countries, and conventional facts on the insurance markets covered in this study. The highlights of this issue will give a theoretical evidence to examine the empirical relationship between insurance market activities and economic growth in these selected countries.

It may be noted that, like banking and stock market activities, the coverage of insurance market activities is extensively wide. There are many insurance market activities that can exhibit the coverage and status of insurance market. At large, there are two important insurance market activities that exemplify the status of insurance market. These are insurance market density (IMD) and insurance market penetration (IMP). Both are again projected in three different ways, namely life insurance, non-life insurance, and total insurance (both life and non-life). This paper precisely confines its analysis to $\mathrm{IMD}^{8}$ activities and their causal link with economic growth in the studied Eurozone countries. 
Characteristically, we intend to examine the trend and regionalization of IMD activities in the Eurozone. We highlight here three activities of IMD, namely life insurance density (LID), non-life insurance density (NID), and total insurance (both life and nonlife) density (TID). A detailed discussion of these variables is available in Appendix C (see Table 9). We use annual data of these variables for both regional disparity discussion and Granger causality investigation. These were obtained from the World Development Indicators of the World Bank and Sigma Economic E Research Consulting of Switzerland.

The study first examines the trend of insurance market activities before studying the Granger causal relationship with economic growth. We present the trend of these activities in four different time periods from 1980 to 2014. These time periods are: Period 1- 1980 to 2000, Period 2- 2001 to 2007, Period 3- 2008 to 2014, and Period 4- 1980 to 2014. These four categorizations have been made with reference to the global financial crisis in the year 2007-2008. The idea is to know the trend of insurance market before and after the global financial crisis, and how the deviation of this market behaves with respect to its overall average from 1980 to 2014. We choose this particular time period on the basis of data availability in the archives.

This study presents the salient facts of three IMD activities across the 19 Eurozone countries. These countries are Austria, Belgium, Cyprus, Estonia, Finland, France, Germany, Greece, Ireland, Italy, Latvia, Lithuania, Luxembourg, Malta, the Netherlands, Portugal, Slovakia, Slovenia, and Spain.

First, the level of life insurance density (LID) is moderately high in comparison to non-life insurance density (NID). This is true for most of the Eurozone countries.

Second, the volume of LID is relatively high in Finland, Ireland, France, and Luxembourg, while it is proportionally low in Latvia, Lithuania, Estonia, and Slovakia. This is true for all the the four time periods.

Third, the volume of NID is considerably high in the Netherlands, Luxembourg, Germany, and Austria, while it is relatively low in Lithuania, Latvia, Estonia, and Slovakia. This is again true for all the four time periods.

Fourth, the volume of TID has great intensity in the Netherlands, Finland, Ireland, Luxembourg, and Belgium, while it is low in Lithuania, Latvia, Estonia, and Slovakia. This is significantly true for all the time periods.

Fifth, the insurance density values are substantially low for Lithuania, Latvia, Estonia, and Slovakia for all the three cases and all the time periods.

Sixth, for all the three insurance density indicators, the Netherlands, Ireland, and Luxembourg record the highest values in all the four time periods.

To summarize, insurance market density (for LID, NID, and TID) is considerably low in Lithuania, Latvia, Estonia, and Slovakia, while it is relatively high in the Netherlands, Ireland and Luxembourg. Furthermore, the extent of regional disparity measured through coefficient of variation has been declining in the Eurozone countries, which is reflected across all periods (P1-P4). The figures are not reported here in order to conserve space.

These typical IMD trends are more or less similar to economic growth trend represented by per capita gross domestic product, and are considerably true for most of the Eurozone countries. In other words, like IMD, the level of economic 
growth $^{9}$ is typically high in like group of countries like the Netherlands, Ireland, and Finland and moderately low in other similar group of countries like Lithuania, Latvia, Estonia, and Slovakia. This, hypothetically, signals that IMD and per capita economic growth have a link and can cause each other in the process of economic development. In the subsequent section, we empirically authenticate this claim in the context of the 19 Eurozone countries, both at individual country level and at the panel level.

\section{Empirical strategy}

This study uses Granger causality test to recognize the evidence of the relationship between insurance market density and economic growth using the Eurozone countries over the period of 1980 to 2014. The period is chosen on the basis of the data availability of insurance market activities (IMA). We use complete archived IMA data available at the time of study, and specifically deploy this particular period (1980-2014) for Granger causality test because of its larger sample size. We propose the following two hypotheses to be tested:

$H_{1 A, B}$ : Insurance market density in any year Granger-causes economic growth, leading to the occurrence of supply-leading hypothesis of insurance-growth nexus.

$H_{2 A}$, B: Economic growth in any year Granger-causes insurance market density, leading to the occurrence of demand-following hypothesis of insurance-growth nexus.

On the empirical front, we deploy per capita gross domestic product $\left(\mathrm{GDP}^{10}\right)$, and three IMD indicators ${ }^{11}$ to validate the above two hypotheses $\left(H_{1 A, B}\right.$ and $\left.H_{2 A, B}\right)$.

Annual data of these variables (GDP, LID, NID, and TID) were obtained from the World Development Indicators of the World Bank and Sigma Economic \& Research Consulting of Switzerland. The summary statistics of these variables ${ }^{12}$ for each country are presented in Table 1.

The study uses the following models to identify the long-run and short-run causal relationships between insurance market density and economic growth.

$$
\text { Economic } \text { Growth }_{i t}=\alpha_{i t}+\beta_{1 i} \text { Insurance Market Density }_{i t}+\varepsilon_{i t}
$$

where,

$i=1,2 \ldots \mathrm{N}$ represents an individual country in the Eurozone panel;

$t=1,2 \ldots$. T refers to the time period $(1980-2014)$; and.

$\varepsilon_{i t}$ is an independent and normally distributed random error with zero mean and a finite heterogeneous variance $\left(\sigma_{i}^{2}\right)$.

Other variations of eq. (1) are also allowed to change the dependent variable from economic growth to insurance market density. When we look for individual country analysis, the subscript ' $i$ ' is removed from eq. (1). The parameter $\beta_{1 i}$ represents the long-run elasticity estimates of economic growth with respect to insurance market density. ${ }^{13}$ The task was to estimate the parameters in eq. (1) and conduct panel tests on the causal nexus between the two variables. It is guessed that $\beta_{1 i}>0$, which suggests that an increase in insurance market density is likely to cause an increase in economic growth. We can also guess the presence of reverse causality by interchanging the position of insurance market density and economic growth in Eq. (1). In other words, we 
Table 1 Descriptive Statistics of Variables

\begin{tabular}{|c|c|c|c|c|}
\hline \multirow[t]{2}{*}{ Countries } & \multicolumn{4}{|l|}{ Variables } \\
\hline & LID & NID & TID & GDP \\
\hline Austria & $2.65[0.39]$ & $2.89[0.25]$ & $3.10[0.30]$ & $1.22[0.04]$ \\
\hline Belgium & $2.81[0.51]$ & $2.81[0.24]$ & $3.14[0.37]$ & $1.22[0.04]$ \\
\hline Cyprus & $2.29[0.48]$ & 2.35 [0.39] & $2.63[0.43]$ & $1.23[0.10]$ \\
\hline Estonia & $1.31[0.67]$ & $1.91[0.53]$ & $2.02[0.55]$ & $1.23[0.40]$ \\
\hline Finland & $3.11[0.38]$ & $2.68[0.23]$ & $3.25[0.34]$ & $1.22[0.11]$ \\
\hline France & $2.94[0.49]$ & $2.83[0.23]$ & $3.21[0.35]$ & $1.21[0.04]$ \\
\hline Germany & $2.76[0.33]$ & $2.91[0.25]$ & $3.14[0.28]$ & $1.22[0.06]$ \\
\hline Greece & 1.83 [0.55] & $2.01[0.37]$ & $2.25[0.42]$ & $1.18[0.11]$ \\
\hline Ireland & $3.03[0.46]$ & $2.74[0.31]$ & $3.22[0.40]$ & $1.25[0.10]$ \\
\hline Italy & $2.46[0.73]$ & $2.61[0.29]$ & $2.89[0.46]$ & $1.20[0.07]$ \\
\hline Latvia & $0.90[0.36]$ & $1.87[0.47]$ & $1.92[0.43]$ & $1.28[0.24]$ \\
\hline Lithuania & 1.18 [0.52] & $1.57[0.56]$ & $1.73[0.53]$ & $1.18[0.43]$ \\
\hline Luxembourg & 3.07 [0.33] & 3.19 [0.13] & $3.34[0.36]$ & $1.24[0.10]$ \\
\hline Malta & $2.52[0.31]$ & $2.47[0.12]$ & $2.81[0.20]$ & $1.24[0.08]$ \\
\hline Netherland & $2.97[0.33]$ & $3.06[0.39]$ & $3.33[0.36]$ & $1.21[0.05]$ \\
\hline Portugal & $2.64[0.46]$ & $2.56[0.17]$ & $2.92[0.31]$ & $1.20[0.07]$ \\
\hline Slovakia & $1.82[0.50]$ & $2.04[0.35]$ & $2.25[0.41]$ & $1.27[0.09]$ \\
\hline Slovenia & $2.13[0.48]$ & $2.70[0.25]$ & $2.81[0.29]$ & $1.23[0.12]$ \\
\hline Spain & $2.33[0.64]$ & $2.54[0.38]$ & $2.77[0.45]$ & $1.22[0.06]$ \\
\hline EZP & $2.55[0.70]$ & $2.61[0.44]$ & 2.90 [0.53] & $1.22[0.13]$ \\
\hline
\end{tabular}

Note 1: GDP is per capita economic growth; LID is life insurance density; NID is non-life insurance density; TID is total insurance density; and EZP is Eurozone panel

Note 2: Open values represent the mean of the variables, while [] represents the standard deviation of the variables Note 3: Values reported here are natural logs of the variables

look forward to recognize the feasibility of feedback relationship (i.e., the bidirectional causality) between insurance market density and economic growth.

The Granger causality test (Granger, 1988) is deployed here to detect the direction of causality (bidirectional/ unidirectional/ neutrality) between insurance market density and economic growth. We deploy the following regression models to observe the direction of causality between insurance market density and economic growth.

Model 1: For individual country analysis

$$
\begin{aligned}
& {\left[\begin{array}{l}
\Delta \text { Economic } \text { Growth }_{t} \\
\Delta \text { Insurance Market Density }
\end{array}\right]=\left[\begin{array}{l}
\mu_{1 I N S} \\
\mu_{2 I N S}
\end{array}\right]+} \\
& \sum_{k=1}^{p}\left[\begin{array}{l}
\delta_{11 I N S 1 k}(L) \delta_{12 k}(L) \\
\delta_{21 I N S 1 k}(L) \delta_{22 k}(L)
\end{array}\right]\left[\begin{array}{l}
\Delta \text { Economic } \\
\text { Growth }
\end{array}\right.
\end{aligned}
$$

The null and alternative hypotheses are to test the following:

$$
\begin{array}{ll}
H_{0}: \delta_{12 k=0} ; \text { and } \eta_{1 k}=0 & \text { for } k=1, \ldots, p \\
H_{A}: d_{12 k \# 0} ; \text { and } \eta_{1 k} \# 0 & \text { for } k=1, \ldots, p \\
H_{0}: \delta_{21 k=0} ; \text { and } \eta_{2 k}=0 & \text { for } k=1, \ldots, p \\
H_{A}: \delta_{21 k \# 0} ; \text { and } \eta_{2 k} \# 0 & \text { for } k=1, \ldots, p
\end{array}
$$


where, $\mathrm{ECT}^{14}$ is error correction term, which is derived from the long-run cointegration equation; and.

$\varepsilon_{i t}$ is an independent and normally distributed random error with a zero mean and a finite heterogeneous variance $\left(\sigma_{i}^{2}\right)$.

Model 2: For panel data analysis

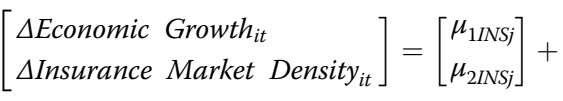

$$
\begin{aligned}
& \sum_{k=1}^{p}\left[\begin{array}{l}
\delta_{11 I N S i k}(L) \delta_{12 i k}(L) \\
\delta_{21 I N S i k}(L) \delta_{22 i k}(L)
\end{array}\right]\left[\begin{array}{l}
\Delta \text { Economic } \text { Growth }_{i t-k} \\
\Delta \text { Insurance }^{\text {Market }} \text { Density }_{i t-k}
\end{array}\right]+\left[\begin{array}{l}
\eta_{1 I N S i} E C T_{1 i t-1} \\
\eta_{2 I N S i} E C T_{2 i t-1}
\end{array}\right]+\left[\begin{array}{l}
\xi_{1 I N S i t} \\
\xi_{2 I N S i t}
\end{array}\right]
\end{aligned}
$$

The null and alternative hypotheses are to test the following:

$$
\begin{array}{ll}
H_{0}: \delta_{12 i k=0} ; \text { and } \eta_{1 i k}=0 & \text { for } k=1, \ldots, p \\
H_{A}: \delta_{12 i k \# 0} ; \text { and } \eta_{1 i k} \# 0 & \text { for } k=1, \ldots, p \\
& \\
H_{0}: \delta_{21 i k=0} ; \text { and } \eta_{2 i k}=0 & \text { for } k=1, \ldots, p \\
H_{A}: \delta_{21 i k \# 0} ; \text { and } \eta_{2 i k} \# 0 & \text { for } k=1, \ldots, p
\end{array}
$$

where, $i=1,2,3, \ldots . . \mathrm{N}$ represents a country in the panel; and $t=1,2,3, \ldots . . \mathrm{T}$ represents a year in the panel.

This study follows the $\mathrm{AIC}^{15}$ statistic to decide the optimum lag length of these two models. Equally, the inclusion of ECT (in both Model 1 and Model 2) exclusively depends upon the condition of order of integration and the cointegrating relationship between insurance market density and economic growth. Hence, the first requirement is to check the order of integration and cointegration between the two (IMD ${ }^{16}$ and GDP). Therefore, we first deploy unit root test and cointegration test, both at the individual country as well as at the panel level, to ascertain the order of integration and the presence of cointegrating relationship between insurance market density and economic growth.

The $\mathrm{ADF}^{17}$ unit root test is used for individual country analysis, while the LLC ${ }^{18}$ panel unit root test is used for the panel setting. In the same way, Johansen Maximum Likelihood cointegration test (Johansen, 1988) is deployed for individual country analysis, while Johansen Fisher panel cointegration test is deployed for the panel setting. The details of these two tests (Johansen and Fisher/ Maddala) are not discussed here due to space constraints and can be made available on request. Additionally, it can be noted that the evidences of cointegration and causality in the panel setting may be sensitive to the assumption of cross-sectional dependence. Hence, we deployed Pesaran (2004) test of cross sectional dependence (CD) to all the four variables. However, CDstatistics do not give any significant results. The results of these statistics are not reported in order to conserve space. 


\section{Empirical results and discussion}

This section begins with the stationarity issue of variables, namely GDP, LID, NID, and TID, and their cointegrating relationships. ${ }^{19}$ First, by using the unit root tests (ADF test for individual country and LLC test for panel setting), we reject the null hypothesis of unit root at the first difference, but not for the levels (see Table 2). This indicates that insurance market density (LID, NID and TID) and economic growth (GDP) are nonstationary at the level data, but are stationary at the first difference. This is true for all the Eurozone countries, both at the individual country and at the panel setting. This suggests that insurance market development (LID, NID, and TID) and economic growth are integrated of order one [i.e., I (1)], which opens the possibility of cointegration between the two.

In the next step, using cointegration test (Johansen Maximum Likelihood cointegration test for individual country and Johansen and Fisher/ Maddala cointegration for panel settings), we find that IMD and GDP are cointegrated, suggesting the existence of long run relationship between insurance market density and economic growth. This finding is consistent with the findings of several earlier studies (see,

Table 2 Results of Unit Root Test

\begin{tabular}{|c|c|c|c|c|}
\hline \multirow[b]{2}{*}{ Countries } & \multicolumn{4}{|l|}{ Variables } \\
\hline & LID & NID & TID & GDP \\
\hline Austria & $2.57\left[-5.44^{*}\right]$ & $2.50\left[-3.59^{*}\right]$ & $2.69\left[-3.61^{*}\right]$ & $0.30\left[-5.44^{*}\right]$ \\
\hline Belgium & $2.78\left[-2.27^{* *}\right]$ & $1.64\left[-3.89^{*}\right]$ & $2.30\left[-3.59^{*}\right]$ & $-0.17\left[-10.2^{*}\right]$ \\
\hline Cyprus & $1.66\left[-5.23^{*}\right]$ & $3.49\left[-2.79^{*}\right]$ & $2.18\left[-4.87^{*}\right]$ & $-0.59[0.22]$ \\
\hline Estonia & $0.70\left[-2.60^{*}\right]$ & $0.78\left[-4.57^{*}\right]$ & $0.92\left[-4.27^{*}\right]$ & $-0.89\left[-5.58^{*}\right]$ \\
\hline Finland & $2.52\left[-3.68^{*}\right]$ & $2.49\left[-3.32^{*}\right]$ & $2.44\left[-3.05^{*}\right]$ & $-0.49\left[-6.19^{*}\right]$ \\
\hline France & $1.24\left[-2.32^{*}\right]$ & $2.26\left[-3.70^{*}\right]$ & $1.55\left[-2.64^{*}\right]$ & $-0.26\left[-6.21^{*}\right]$ \\
\hline Germany & $3.01\left[-3.38^{*}\right]$ & $2.45\left[-3.40^{*}\right]$ & $2.75\left[-3.36^{*}\right]$ & $-0.35\left[-5.63^{*}\right]$ \\
\hline Greece & $1.06\left[-2.17^{* *}\right]$ & $2.06\left[-3.52^{*}\right]$ & $1.34\left[-2.96^{*}\right]$ & $-0.12\left[-5.61^{*}\right]$ \\
\hline Ireland & $1.81\left[-3.87^{*}\right]$ & $1.11\left[-3.95^{*}\right]$ & $1.77\left[-3.60^{*}\right]$ & $-0.08\left[-5.91^{*}\right]$ \\
\hline Italy & $4.06\left[-2.98^{*}\right]$ & $2.53\left[-3.41^{*}\right]$ & $4.03\left[-6.45^{*}\right]$ & $-0.67\left[-7.37^{*}\right]$ \\
\hline Latvia & $1.21\left[-2.79^{*}\right]$ & $1.11\left[-1.78^{* * *}\right]$ & $1.33\left[-1.68^{* * *}\right]$ & $-0.41\left[-4.59^{*}\right]$ \\
\hline Lithuania & $0.92\left[-3.10^{*}\right]$ & $1.40\left[-3.18^{*}\right]$ & $0.84\left[-3.18^{*}\right]$ & $-0.74\left[-3.70^{*}\right]$ \\
\hline Luxembourg & $1.82\left[-4.92^{*}\right]$ & $2.27\left[-2.55^{*}\right]$ & $2.02\left[-4.00^{*}\right]$ & $-0.23\left[-6.52^{*}\right]$ \\
\hline Malta & $-0.17\left[-1.38^{* * *}\right]$ & $0.26\left[-5.82^{*}\right]$ & $1.63\left[-3.74^{*}\right]$ & $-0.13\left[-6.43^{*}\right]$ \\
\hline Netherlands & $1.68\left[-4.11^{*}\right]$ & $2.36\left[-4.25^{*}\right]$ & $2.53\left[-4.08^{*}\right]$ & $-0.12\left[-6.53^{*}\right]$ \\
\hline Portugal & $2.50\left[-3.67^{*}\right]$ & $1.28\left[-3.01^{*}\right]$ & $3.00\left[-3.74^{*}\right]$ & $-1.60\left[-5.04^{*}\right]$ \\
\hline Slovakia & $1.41\left[-1.89^{* * *}\right]$ & $1.18\left[-2.20^{* *}\right]$ & $1.49\left[-2.04^{* *}\right]$ & $-0.15\left[-6.24^{*}\right]$ \\
\hline Slovenia & $0.70\left[-1.71^{* * *}\right]$ & $1.55\left[-2.57^{* *}\right]$ & $1.29\left[-2.17^{* *}\right]$ & $-0.46\left[-4.99^{*}\right]$ \\
\hline Spain & $0.61\left[-4.93^{*}\right]$ & $1.26\left[-2.80^{*}\right]$ & $1.54\left[-4.26^{*}\right]$ & $-0.09\left[-6.31^{*}\right]$ \\
\hline EZP & $4.39\left[155.1^{*}\right]$ & $5.54\left[184.4^{*}\right]$ & $5.41\left[167.8^{*}\right]$ & $21.7\left[486.9^{*}\right]$ \\
\hline
\end{tabular}

Note 1: GDP is per capita economic growth; LID is life insurance density; NID is non-life insurance density; TID is total insurance density; and EZP is Eurozone panel

Note 2: Open values represent the ADF statistics of the variables at the level data, while [] represents the ADF statistics of the variables at the first difference data

Note 3: ADF is Augmented Dickey Fuller test statistics

Note 4: The investigation is done at three levels- no trend and intercept, with intercept, and with both intercept and trend. The results are more or less uniform; however, the reported statistics in the table present the ADF statistics at no trend and no intercept

Note 5: * is statistical significance at $1 \%$ level; ${ }^{* *}$ is statistical significance at $5 \%$ level; and *** is statistical significance at $10 \%$ level 
inter alia, Petkovski and Jordan 2014; Pradhan et al. 2017). However, cointegration between GDP and IMD does not exist in some Eurozone countries. These exceptions are Cyprus, Finland, Greece, Latvia, Lithuania, Malta, Slovakia, and Slovenia (see Table 3). A summary of these findings has been highlighted in Table 4.

The next step is to determine the direction of causality between insurance market density and per capita economic growth. The Granger causality test, based on vector error correction model $\left(\mathrm{VECM}^{20}\right)$, was deployed to test the direction of Granger causality between insurance market density and per capita economic growth. The estimated results of this section are reported in Tables 5, 6 and 7. Table 5 reports both short-run and long-run estimates ${ }^{21}$ of VECM/VARM, while Tables 6 and 7 report the summary of short-run Granger causality results.

Table 5 reports the presence of a long-run equilibrium relationship between insurance market density and economic growth, while Tables 6 and 7 report the short-run Granger causality between the two. The analysis is based on three individual indicators of insurance market density (such as LID, NID, and TID) and economic growth. With respect to long-run equilibrium relationship, we find the

Table 3 Results of Cointegration Test

\begin{tabular}{|c|c|c|c|c|c|c|}
\hline \multirow[t]{5}{*}{ Countries } & \multicolumn{6}{|c|}{ Variables (with GDP) } \\
\hline & \multicolumn{2}{|l|}{ LID } & \multicolumn{2}{|l|}{ NID } & \multicolumn{2}{|l|}{ TID } \\
\hline & $\overline{\lambda_{\text {Tra }}}$ & $\lambda_{\operatorname{Max}}$ & $\lambda_{\text {Tra }}$ & $\lambda_{\operatorname{Max}}$ & $\overline{\lambda_{\text {Tra }}}$ & $\lambda_{\operatorname{Max}}$ \\
\hline & $r=0 ; r=1$ & $r=0 ; r=1$ & $r=0 ; r=1$ & $r=0 ; r=1$ & $r=0 ; r=1$ & $r=0 ; r=1$ \\
\hline & {$[r \leq 1 ; r=2]$} & {$[r \leq 1 ; r=2]$} & {$[r \leq 1 ; r=2]$} & {$[r \leq 1 ; r=2]$} & {$[r \leq 1 ; r=2]$} & {$[r \leq 1 ; r=2]$} \\
\hline Austria & $22.5^{* *}[3.77]$ & $18.7^{* *}[3.77]$ & $22.2^{* *}[2.02]$ & $20.1^{* *}[2.02]$ & $21.95^{* *}[2.65]$ & $19.3^{* *}[2.65]$ \\
\hline Belgium & $17.2^{* *}[1.87]$ & $15.35^{* *}[1.89]$ & $13.8[1.68]$ & $16.1^{* *}[1.68]$ & $15.5^{* *}[1.69]$ & $13.8[1.69]$ \\
\hline Cyprus & $11.3[3.79]$ & 7.49 [3.79] & $13.4[3.07]$ & $10.3[3.07]$ & $11.1[2.80]$ & $8.28[2.80]$ \\
\hline Estonia & $18.8^{* *}[2.41]$ & $16.4^{* *}[2.41]$ & $20.4^{* *}[1.62]$ & $18.8^{* *}[1.62]$ & $13.7[2.07]$ & $11.6[2.07]$ \\
\hline Finland & 13.9 [1.22] & $12.6[1.22]$ & 14.9 [2.62] & $12.3[2.62]$ & $14.2[1.42]$ & $12.8[1.42]$ \\
\hline France & $18.4^{* *}\left[4.62^{* *}\right]$ & $15.7^{* *}[4.62]$ & $15.5^{* *}[3.84]$ & $15.5^{* *}\left[4.62^{* *}\right]$ & $17.0^{* *}[3.18]$ & $13.8[3.18]$ \\
\hline Germany & $24.8^{* *}[3.25]$ & $21.5^{* *}[3.25]$ & $23.8^{* *}[3.03]$ & $20.8^{* *}[3.03]$ & $24.3^{* *}[3.06]$ & $21.2^{* *}[3.06]$ \\
\hline Greece & $14.5[3.23]$ & $9.29[3.23]$ & $12.9[0.69]$ & $12.3[0.64]$ & $12.2[1.37]$ & $10.9[1.37]$ \\
\hline Ireland & $20.6^{* *}[3.29]$ & $17.3^{* *}[3.29]$ & $17.5^{* *}[3.78]$ & 8.69 [3.78] & $19.2^{* *}[3.46]$ & $15.7^{* *}[3.46]$ \\
\hline Italy & $22.0^{* *}\left[4.01^{* *}\right]$ & $18.0^{* *}\left[4.01^{* *}\right]$ & $18.5^{* *}\left[5.36^{* *}\right]$ & $18.5^{* *}\left[5.36^{* *}\right]$ & $19.9^{* *}\left[4.11^{* *}\right]$ & $16.9^{* *}\left[4.11^{* *}\right]$ \\
\hline Latvia & $13.7[0.70]$ & $13.0[0.70]$ & $10.3[2.06]$ & 8.18 [2.06] & 8.37 [1.58] & 6.79 [1.58] \\
\hline Lithuania & $46.8^{* *}\left[10.9^{* *}\right]$ & $35.9^{* *}\left[10.9^{* *}\right]$ & $20.1^{* *}[2.28]$ & $17.8^{* *}[2.28]$ & $39.6^{* *}\left[13.0^{* *}\right]$ & $126.6^{* *}\left[13.0^{* *}\right]$ \\
\hline Luxembourg & $16.4^{* *}[0.39]$ & $15.9^{* *}[0.39]$ & 11.9 [0.32] & $11.6[0.32]$ & $12.9[3.15]$ & $9.76[3.15]$ \\
\hline Malta & $13.8[3.15]$ & 9.68 [3.15] & $17.0^{* *}\left[4.38^{* *}\right]$ & $14.6^{* *}\left[4.38^{* *}\right]$ & $16.1^{* *}[2.67]$ & $14.5^{* *}[2.67]$ \\
\hline Netherlands & $22.2^{* *}\left[5.45^{* *}\right]$ & $16.8^{* *}\left[5.45^{* *}\right]$ & $17.9^{* *}[0.34]$ & $17.5^{* *}[0.34]$ & $18.3^{* *}[1.80]$ & $16.5^{* *}[1.80]$ \\
\hline Portugal & $17.6^{* *}\left[3.84^{* *}\right]$ & $15.2^{* *}\left[3.84^{* *}\right]$ & 12.6 [1.73] & 10.9 [1.73] & $16.4^{* *}[1.08]$ & $15.3^{* *}[1.08]$ \\
\hline Slovakia & $22.7^{* *}\left[3.94^{* *}\right]$ & $18.8^{* *}\left[3.94^{* *}\right]$ & $10.2[2.32]$ & 7.90 [2.32] & $12.6[3.13]$ & 9.49 [3.13] \\
\hline Slovenia & $13.9[2.12]$ & $12.8[2.12]$ & $12.4[2.65]$ & 11.7 [2.65] & 13.5 [3.38] & $12.2[3.38]$ \\
\hline Spain & $13.8[3.00]$ & $9.79[3.00]$ & 12.0 [3.29] & 8.70 [3.29] & $14.1[3.91]$ & $10.2[3.91]$ \\
\hline EZP & $170.0^{* *}\left[113^{* *}\right]$ & $136^{* *}\left[113^{* *}\right]$ & $109^{* *}\left[77.3^{* *}\right]$ & $94.4^{* *}\left[77.3^{* *}\right]$ & $141^{* *}\left[91^{* *}\right]$ & $117^{* *}\left[91^{* *}\right]$ \\
\hline
\end{tabular}

Note 1: GDP is per capita economic growth; LID is life insurance density; NID is non-life insurance density; TID is total insurance density; and EZP is Eurozone panel

Note 2: $r$ is the co-integrating vector

Note 3: The cointegration test conclusions are reported on the basis of Johansen and Juselius test

Note $4:{ }^{* *}$ is statistical significance at $5 \%$ level

Note 5: The Johansen test follows the assumptions 'no trend and no intercept' 
Table 4 Summary of Cointegration Test Results

\begin{tabular}{|c|c|c|c|c|c|}
\hline \multicolumn{3}{|l|}{ Cointegrated } & \multicolumn{3}{|c|}{ Not Cointegrated } \\
\hline Case 1 & Case 2 & Case 3 & Case 1 & Case 2 & Case 3 \\
\hline Austria (1) & Austria (1) & Austria (1) & & & \\
\hline \multirow[t]{2}{*}{ Belgium (1) } & Belgium (1) & Belgium (1) & & & \\
\hline & & & Cyprus (0) & Cyprus (0) & Cyprus (0) \\
\hline \multirow[t]{2}{*}{ Estonia (1) } & Estonia (1) & & & & Estonia (0) \\
\hline & & & Finland (0) & Finland (0) & Finland (0) \\
\hline France (2) & France (2) & France (1) & & & \\
\hline \multirow[t]{2}{*}{ Germany (1) } & Germany (1) & Germany (1) & & & \\
\hline & & & Greece (0) & Greece (0) & Greece (0) \\
\hline Ireland (1) & Ireland (1) & Ireland (1) & & & \\
\hline \multirow[t]{2}{*}{ Italy (2) } & Italy (2) & Italy (2) & & & \\
\hline & & & Latvia (0) & Latvia (0) & Latvia (0) \\
\hline Lithuania (2) & Lithuania (1) & Lithuania (2) & & & \\
\hline \multirow[t]{2}{*}{ Luxembourg (1) } & & & & Luxembourg (0) & Luxembourg (0) \\
\hline & Malta (2) & Malta (1) & Malta (0) & & \\
\hline Netherlands (2) & Netherlands (1) & Netherlands (1) & & & \\
\hline Portugal (2) & & Portugal (1) & & Portugal (0) & \\
\hline Slovakia (2) & & & & Slovakia (0) & Slovakia (0) \\
\hline Slovenia (0) & Slovenia (0) & Slovenia (0) & & & \\
\hline Spain (0) & Spain (0) & Spain (0) & & & \\
\hline EZP (2) & EZP Panel (2) & EZP panel (2) & & & \\
\hline
\end{tabular}

Note 1: Case 1: cointegration between LID and GDP; Case 2: cointegration between NID and GDP; and Case 3: cointegration between TID and GDP

Note 2: GDP is per capita economic growth; LID is life insurance density; NID is non-life insurance density; TID is total insurance density; and EZP is Eurozone panel

Note 3: 0 stands for absence of cointegration between insurance market density (LID/ NID/ TID) and per capita economic growth, 1 stands for presence of one cointegrating vector between insurance market density (LID/ NID/ TID) and per capita economic growth, and 2 stands for presence of two cointegrating vectors between insurance market density (LID/ NID/ TID) and per capita economic growth

Note 4: Parentheses indicate number of cointegrating vector(s)

Note 5: Results are derived on the basis of Table 3 results

presence in a few situations and absence in other situations. This is true while studying Granger causality from insurance market density (LID/NID/TID) to per capita economic growth, and vice versa. On the other hand, we have an experience of divergence in the context of short-run Granger causality between insurance market density and economic growth. The results of this section are presented below.

\section{Case 1: Between life insurance density and per capita economic growth}

For Belgium, Cyprus, Estonia, Finland, Latvia, Lithuania, Luxembourg, Malta, the Netherlands, and Portugal, there is a unidirectional causality from life insurance market density (LID) to economic growth (GDP) [LID $=>$ GDP]. This supports the supply-leading hypothesis $\left(S L H^{1}\right)$ of insurance market-growth nexus (see column 5 of Table 6). This finding is consistent with the findings of earlier studies by Alhassan and Biekpe (2016), Pradhan et al. (2017), Alhassan and Fiador (2014), Webb et al. (2005a), Chang et al. (2014), Guochen and Wei (2012), Lee (2011), 
Table 5 Results of Test from the Vector Error Correction Model for Long-Run Causality

\begin{tabular}{|c|c|c|c|}
\hline \multirow[b]{2}{*}{ Countries } & \multicolumn{3}{|c|}{ Dependent Variables } \\
\hline & LID/ GDP & NID/ GDP & $\mathrm{TID} / \mathrm{GDP}$ \\
\hline Austria & $-0.19 /-3.34^{* *}$ & $-0.41 /-3.40^{* *}$ & $-0.33 /-3.35^{* *}$ \\
\hline Belgium & $-01.3 /-3.90^{* *}$ & $-0.12 /-3.13^{* *}$ & $0.25 /-3.50^{* *}$ \\
\hline Cyprus & $---1---$ & $---1---$ & $---1---$ \\
\hline Estonia & $0.23 /-3.29^{* *}$ & $-2.91 /-3.22^{* *}$ & $-0.94 /-3.85^{* *}$ \\
\hline Finland & $---1---$ & $---1---$ & $---1--$ \\
\hline France & $-0.84 /-3.67^{* *}$ & $-0.49 /-3.30^{* *}$ & $-0.74 /-2.95^{* *}$ \\
\hline Germany & $1.37 /-4.99^{* *}$ & $1.40 /-4.95^{* *}$ & $1.39 /-4.96^{* *}$ \\
\hline Greece & $--1---$ & $--1---$ & $--1--$ \\
\hline Ireland & $2.39 / 0.82$ & $1.78 /-1.23$ & $2.33 / 0.14$ \\
\hline Italy & $2.05 /-3.24^{* *}$ & $2.03 /-1.62$ & $2.26 /-3.08^{* *}$ \\
\hline Latvia & $---1---$ & $---1---$ & $---1---$ \\
\hline Lithuania & $--1---$ & $---1---$ & $---1---$ \\
\hline Luxembourg & $0.63 /-2.05$ & $---1---$ & $---1---$ \\
\hline Malta & $---1---$ & $---1---$ & $---1---$ \\
\hline Netherlands & $0.62 /-2.58$ & $-0.86 /-2.95^{* *}$ & $-1.77 /-3.63^{* *}$ \\
\hline Portugal & $-0.80 /-2.88^{* *}$ & $---1---$ & $0.44 /-3.67^{* *}$ \\
\hline Slovakia & $---1---$ & $---1---$ & $---1---$ \\
\hline Slovenia & $---1---$ & $---1---$ & $---1---$ \\
\hline Spain & $-2.02 /-2.34$ & $---1---$ & $---/$ - - \\
\hline EZP & $-11.98^{* *} /-3.76^{* *}$ & $-10.10^{* *} /-3.49^{* *}$ & $-10.9^{* *} /-4.27^{* *}$ \\
\hline
\end{tabular}

Note 1: GDP is per capita economic growth; LID is life insurance density; NID is non-life insurance density; TID is total insurance density; and EZP is Eurozone panel Note 2: The figures are the t-coefficients of lagged error correction term Note $3:{ }^{*}$ is statistical significance at $5 \%$ level

Arena (2008), Kugler and Ofoghi (2005), and Catalan et al. (2000). For, Germany, Greece, Slovakia, and Slovenia, we find the presence of unidirectional causality from economic growth to life insurance density [GDP $=>$ LID]. This supports the demand-following hypothesis $\left(D F H^{1}\right)$ of insurance market-growth nexus. This finding is consistent with the findings of earlier studies by Alhassan and Biekpe (2016), Pradhan et al. (2015a, 2015b), Chang et al. (2014), Guochen and Wei (2012), Lee (2011), Ching et al. (2010), and Catalan et al. (2000). Furthermore, for Ireland, Italy, and the European Zone panel, there is a bidirectional causality between life insurance density and economic growth (LID $<=>$ GDP]. This supports the feedback hypothesis $\left(F B H^{1}\right)$ of insurance market-growth nexus. ${ }^{22}$ This finding is consistent with the findings of earlier studies by Alhassan and Biekpe (2016), Pradhan et al. (2015a, 2015b), Chang et al. (2014), Guochen and Wei (2012), and Kugler and Ofoghi (2005).

\section{Case 2: Between non-life insurance density and per capita economic growth}

For Cyprus, France, Lithuania, Luxembourg, the Netherlands, and Slovenia, there is a unidirectional causality from non-life insurance market density (NID) to economic growth [NID $=>$ GDP], offering support to the supply-leading hypothesis $\left(S L H^{2}\right)$ of insurance market-growth nexus. This finding is consistent with the 
Table 6 Granger Causality Test Results for the Short run

\begin{tabular}{|c|c|c|c|c|}
\hline \multirow[b]{3}{*}{ Countries } & \multicolumn{4}{|c|}{ Possible Granger Causalities } \\
\hline & & & & Granger Causality \\
\hline & GDP vs. LID & GDP vs. NID & GDP vs. TID & Inferences \\
\hline Austria & $1.70 / 1.48$ & $1.17 / 3.46^{* *}$ & $1.15 / 2.74$ & $\mathrm{NLH}^{1}, \mathrm{DFH}^{2}, \mathrm{NLH}^{3}$ \\
\hline Belgium & $5.90^{* *} / 0.50$ & $1.23 / 0.78$ & $3.20 * * / 0.71$ & $\mathrm{SLH}^{1}, \mathrm{NLH}^{2}, \mathrm{SLH}^{3}$ \\
\hline Cyprus & $4.83^{* *} / 0.12$ & $7.89 * * / 2.05$ & $5.84^{* *} / 0.10$ & $S L H^{1}, S L H^{2}, S L H^{3}$ \\
\hline Estonia & $12.1^{* *} / 0.34$ & $7.20^{* *} / 17.1^{* *}$ & $15.9^{* *} / 1.88$ & $\mathrm{SLH}^{1}, \mathrm{FBH}^{2}, \mathrm{SLH}$ \\
\hline Finland & $3.81^{* *} / 2.68$ & $5.04^{* *} / 5.83^{* *}$ & $4.40^{* *} / 3.01^{* *}$ & $\mathrm{SLH}^{1}, \mathrm{FBH}^{2}, \mathrm{FBH}^{3}$ \\
\hline France & $1.81 / 0.61$ & $5.68^{* *} / 1.70$ & $3.25 * * / 0.05$ & $\mathrm{NLH}^{1}, \mathrm{SLH}^{2}, \mathrm{SLH}^{3}$ \\
\hline Germany & $0.51 / 3.39^{* *}$ & $0.75 / 3.35^{* *}$ & $0.61 / 3.57^{* *}$ & $\mathrm{DFH}^{1}, \mathrm{DFH}^{2}, \mathrm{DFH}^{3}$ \\
\hline Greece & $0.74 / 7.21^{* *}$ & $1.69 / 8.93^{* *}$ & $1.39 / 8.60^{* *}$ & $\mathrm{DFH}^{1}, \mathrm{DFH}^{2}, \mathrm{DFH}^{3}$ \\
\hline Ireland & $17.4^{* *} / 4.12^{* *}$ & $0.64 / 3.19^{* *}$ & $8.82^{* *} / 4.10^{* *}$ & $\mathrm{FBH}^{1}, \mathrm{DFH}^{2}, \mathrm{FBH}^{3}$ \\
\hline Italy & $10.5^{* *} / 4.64^{* *}$ & $0.69 / 3.15^{* *}$ & $5.46^{* *} / 5.60^{* *}$ & $\mathrm{FBH}^{1}, \mathrm{DFH}^{2}, \mathrm{FBH}^{3}$ \\
\hline Latvia & $4.93^{* *} / 0.19$ & $6.24^{* *} / 4.68^{* *}$ & $5.19^{* *} / 3.41^{* *}$ & $\mathrm{SLH}^{1}, \mathrm{FBH}^{2}, \mathrm{FBH}^{3}$ \\
\hline Lithuania & $10.9^{* *} / 2.96$ & $8.20 * * / 0.81$ & $3.93^{* *} / 3.42^{* *}$ & $\mathrm{SLH}^{1}, \mathrm{SLH}^{2}, \mathrm{FBH}^{3}$ \\
\hline Luxembourg & $4.70^{* *} / 1.91$ & $3.86^{* *} / 0.02$ & $4.85^{* *} / 0.94$ & $\mathrm{SLH}^{1}, \mathrm{SLH}^{2}, \mathrm{SLH}^{3}$ \\
\hline Malta & $4.95^{* *} / 2.04$ & $0.41 / 5.35^{* *}$ & $0.14 / 6.70^{* *}$ & $\mathrm{SLH}^{1}, \mathrm{DFH}^{2}, \mathrm{DFH}^{3}$ \\
\hline Netherland & $4.95^{* *} / 2.04$ & $3.60^{* *} / 1.63$ & $10.8^{* *} / 5.44^{* *}$ & $\mathrm{SLH}^{1}, \mathrm{SLH}^{2}, \mathrm{FBH}^{3}$ \\
\hline Portugal & $3.81^{* *} / 1.12$ & $1.78 / 8.85^{* *}$ & $3.89^{* *} / 2.85$ & $\mathrm{SLH}^{1}, \mathrm{DFH}^{2}, \mathrm{SLH}^{3}$ \\
\hline Slovakia & $1.13 / 4.62^{* *}$ & $1.64 / 6.96^{* *}$ & $3.81^{* *} / 8.47^{* *}$ & $\mathrm{DFH}^{1}, \mathrm{DFH}^{2}, \mathrm{FBH}^{3}$ \\
\hline Slovenia & $0.74 / 4.40^{* *}$ & $3.41^{* *} / 2.52$ & $3.03^{* *} / 2.73$ & $\mathrm{DFH}^{1}, \mathrm{SLH}^{2}, \mathrm{SLH}^{3}$ \\
\hline Spain & $1.61 / 2.46$ & $3.23^{* *} / 7.55^{* *}$ & $0.31 / 7.72^{* *}$ & $\mathrm{NLH}^{1}, \mathrm{FBH}^{2}, \mathrm{DFH}^{3}$ \\
\hline EZP & $18.63^{* *} / 4.23^{* *}$ & $5.78^{* *} / 6.25^{* *}$ & $4.13^{* *} / 6.23^{* *}$ & $\mathrm{FBH}^{1}, \mathrm{FBH}^{2}, \mathrm{FBH}^{3}$ \\
\hline
\end{tabular}

Note 1: GDP is per capita economic growth; LID is life insurance density; NID is non-life insurance density; TID is total insurance density; and EZP is Eurozone panel

Note 2: FBH is feedback hypothesis between per capita economic growth and insurance market density; SLH is supply leading hypothesis from insurance market density to per capita economic; DFH is demand following hypothesis from per capita economic growth to insurance market density; and NLH is neutrality hypothesis between per capita economic growth and insurance market density

Note $3:{ }^{1}$ : Granger causality between LID and GDP; ${ }^{2}$ : Granger causality between NID and GDP; and ${ }^{3}$ : Granger causality between TID and GDP

Note $4:{ }^{* *}$ is statistical significance at $5 \%$ level

Note 5: The reported figures are Wald test statistics

findings of earlier studies by Alhassan and Biekpe (2016), Pradhan et al. (2017), Alhassan and Fiador (2014), Chang et al. (2014), Guochen and Wei (2012), Lee (2011), Arena (2008), Kugler and Ofoghi (2005), Webb et al. (2005a), and Catalan et al. (2000). For, Austria, Germany, Greece, Ireland, Italy, Malta, Portugal, and Slovakia, we find the presence of unidirectional causality from economic growth to non-life insurance density [GDP $=>$ NID], lending support the demand-following hypothesis $\left(D F H^{2}\right)$ of insurance market-growth nexus. This finding is consistent with the findings of earlier studies by Alhassan and Biekpe (2016), Pradhan et al. (2015a, 2015b), Chang et al. (2014), Guochen and Wei (2012), Lee (2011), and Catalan et al. (2000). Furthermore, for Estonia, Finland, Latvia, Spain, and the European Zone panel, there is a bidirectional causality between non-life insurance density and economic growth (NID $<=>$ GDP], testifying the presence of feedback hypothesis $\left(F B H^{2}\right)$ of insurance market-growth nexus. This finding is consistent with the findings of earlier studies by Alhassan and Biekpe (2016), Pradhan et al. (2015a, 2015b), and Chang et al. (2014). 
Table 7 Summary of Granger Causality Test Results

\begin{tabular}{|c|c|c|c|c|c|}
\hline \multicolumn{3}{|c|}{$\begin{array}{l}\text { Supply-leading hypothesis of insurance-growth } \\
\text { nexus }\end{array}$} & \multicolumn{3}{|c|}{$\begin{array}{l}\text { Demand-following hypothesis of insurance-growth } \\
\text { nexus }\end{array}$} \\
\hline Case 1 & Case 2 & Case 3 & Case 1 & Case 2 & Case 3 \\
\hline Belgium & & Belgium & & Austria & \\
\hline Cyprus & Cyprus & Cyprus & Germany & Germany & Germany \\
\hline Estonia & & Estonia & Greece & Greece & Greece \\
\hline \multirow[t]{2}{*}{ Finland } & & & & Ireland & \\
\hline & France & France & & Italy & \\
\hline Latvia & & & & Malta & Malta \\
\hline Lithuania & Lithuania & & & Portugal & \\
\hline Luxembourg & Luxembourg & Luxembourg & Slovakia & Slovakia & \\
\hline Malta & & & Slovenia & & \\
\hline Netherlands & Netherlands & & & & Spain \\
\hline \multirow[t]{2}{*}{ Portugal } & & Protugal & & & \\
\hline & Slovenia & Slovenia & & & \\
\hline \multicolumn{3}{|c|}{ Feedback hypothesis of insurance-growth nexus } & \multicolumn{3}{|c|}{ Neutrality hypothesis of insurance-growth nexus } \\
\hline \multirow[t]{3}{*}{ Case 1} & Case 2 & Case 3 & Case 1 & Case 2 & Case 3 \\
\hline & Estonia & & Austria & & Austria \\
\hline & Finland & Finland & & Belgium & \\
\hline Ireland & & Ireland & France & & \\
\hline \multirow[t]{6}{*}{ Italy } & & Italy & Spain & & \\
\hline & Latvia & Latvia & & & \\
\hline & & Lithuania & & & \\
\hline & & Netherlands & & & \\
\hline & & Slovakia & & & \\
\hline & Spain & & & & \\
\hline EZP & EZP & EZP & & & \\
\hline
\end{tabular}

Note 1: Case 1: Granger causality between LID and GDP; Case 2: Granger causality between NID and GDP; and Case 3: Granger causality between TID and GDP

Note 2: GDP is per capita economic growth; LID is life insurance density; NID is non-life insurance density; TID is total insurance density; and EZP is Eurozone panel

Note 3: Results are derived on the basis of Table 6 results

\section{Case 3: Between total insurance density and per capita economic growth}

For Belgium, Cyprus, Estonia, France, Luxembourg, Portugal, and Slovenia, there is a unidirectional causality from total insurance market density (TID) to economic growth [TID $=>$ GDP], lending support to the supply-leading hypothesis $\left(\mathrm{SLH}^{3}\right)$ of insurance market-growth nexus. This finding is consistent with the findings of earlier studies by Alhassan and Biekpe (2016), Pradhan et al. (2017), Alhassan and Fiador (2014), Chang et al. (2014), Guochen and Wei (2012), Nejad and Kermani (2012); Kugler and Ofoghi (2005), Boon (2005), and Ward and Zurbruegg (2000). For, Germany, Greece, Malta, and Spain, we find the presence of unidirectional causality from economic growth to total life insurance density [GDP $=>$ TID], thus supporting the demand-following hypothesis $\left(D F H^{3}\right)$ of insurance marketgrowth nexus. This finding is consistent with the findings of earlier studies by Alhassan and Biekpe (2016), Pradhan et al. (2015a, 2015b), Chang et al. (2014), and Guochen and Wei (2012). Additionally, for Finland, Ireland, Italy, Latvia, 
Lithuania, the Netherlands, Slovakia, and the European Zone panel, there is a bidirectional causality between total insurance density and economic growth (TID < => GDP], supporting the feedback hypothesis $\left(F B H^{3}\right)$ of insurance marketgrowth nexus. This finding is consistent with the findings of earlier studies by Alhassan and Biekpe (2016), and Pradhan et al. (2015a, 2015b).

We have also studied the relationship between insurance market activities and economic growth at the multivariate level by deploying three additional variables, such as finical depth, ${ }^{23}$ government consumption expenditure, and young dependency population. Here, we observe six cases, depending upon the deployment of three insurance market activities (life insurance density, non-life insurance density and total insurance density), and two financial depth indicators. The results of this section are reported in Appendix D (see Tables 10-11). The findings of this multivariate analysis are more or less similar to the findings of bivariate analysis. In the long-run, we find economic growth tends to converge to its long-run equilibrium path in response to changes in insurance market activities and three macroeconomic indicators. ${ }^{24}$ This is relatively true for all these six cases considered. However, in the short-run, we find both bidirectional and unidirectional Granger causality between economic growth, insurance market activities, financial depth, government consumption expenditure, and young dependency of population among our panel of countries.

\section{Conclusions}

This study explored the nexus between the insurance market and economic growth for the Eurozone countries using time series data from 1980 to 2014. The focal message from our study for both policymakers and researchers is that implications drawn from research on per capita economic growth that excludes the dynamic interrelation of these two variables will be imperfect. It is the conjoined back-and-forth relationship between insurance market and economic growth, that is, the stand point of our study and directs future research in this field.

Our study finds mixed evidence on the interrelationship between insurance market density and economic growth in the Eurozone countries, both at the individual country level and at the panel setting. On some occasions, insurance market density leads to economic growth, lending support to supply-leading hypothesis of insurance market-growth nexus. On other occasions, economic growth leads to insurance market density, providing support to demand-following hypothesis of insurance market-growth nexus. For countries that support the supply-leading hypothesis, we could argue that insurance market activities are fully developed in those countries, and hence, contribute to economic growth. However, in countries that support the demand-following hypothesis, we may argue that insurance market activities in these countries, even though growing during this period, are either deficient or have impacted economic growth indirectly, possibly through other financial indicators like banks and stock markets. The latter part is, in fact, beyond the scope of this study. There are also situations, where insurance market density and economic growth are interdependent on each other, offering support to the feedback hypothesis of insurance market-growth nexus. In addition, there are also cases, where insurance market density and economic growth are independent of each other, lending support to 
the neutrality hypothesis of insurance-growth nexus. These findings are on the lines of Chang et al. ${ }^{25}$ (2014), Guochen and Wei ${ }^{26}$ (2012), and Pradhan et al. ${ }^{27}$ (2015a, 2015b).

Finally, the study suggests that in order to promote per capita economic growth, attention must be paid to policies that promote the insurance market. This requires an efficient allocation of financial resources combined with wide-ranging movement in the insurance market. Furthermore, establishing a well-developed financial system, particularly with reference to the insurance market, can facilitate further investment and easier means of raising capital to support economic development. Given the possibility of reverse causality or bi-directional causality on some occasions, policies that increase economic growth (such as steps to increase investment) would be desirable to bring insurance market development. Therefore, it is recommended that the government be proactive if it aims to develop the insurance market and integrate it with economic growth.

No doubt, in the globalization era, many developing countries have recognized the importance of financial market development for high economic growth. Accordingly, there has been a change of strategy to refine their financial system. Earlier studies mostly focused on both banking and stock markets and their link with economic growth to stimulate the financial development. However, there is now a need to concentrate on the insurance market by eliminating some of the hindrances in the insurance market-growth nexus, such as tax and regulatory framework, and drive towards more insurance market activities.

To summarize, government must be attentive in its attempts to bring stable financial environment in order to promote the link between insurance market and economic growth. This study is restricted to insurance market density only, and particularly in a bivariate framework of insurance-market growth nexus. It is also one of the major limitations of this empirical investigation. Future studies can include insurance market penetration and other relevant variables, like interest rates or other financial indicators, to gain better inference of the link between the insurance market and economic growth.

\section{Endnotes}

${ }^{1}$ It involves the development of banking sector, stock markets, and insurance markets. However, a majority of the studies largely focus on banking sector and stock markets; and neglect the insurance market (see, inter alia, Azman-Saini and Smith, 2011).

${ }^{2}$ They have emerged as a vital component of new marketplace financial restructuring (see, inter alia, Cristea et al., 2014).

${ }^{3}$ See, for example, Alhassan and Biekpe (2016); Liu and Lee (2014); Guo and Huang (2013); Chang et al. (2013); Altunbas and Thornton (2013); Ghosh (2013); Garcia (2012); Chang and Lee (2012); Azman-Saini and Smith (2011); Guochen and Wei (2012); Lee (2011); Han et al. (2010); Nektarios (2010); Webb et al. (2005); Enz (2000); Moshirian (1999); Outreville (1990); Wasow and Hill (1986); and Beenstock et al. (1986).

${ }^{4}$ Eurozone is a group, instituted in 1957, when the Treaty of Rome created the European Economic Community. This group is a subset of European Union that has fully incorporated the Euro as their sole national currency (see, inter alia, Pegkas 2015). The choice of 
this group, for our empirical investigation, is mostly due to lack of literature in this problem area, and the subsequent data availability for the insurance market activities.

${ }^{5}$ Beck and Demirguc-Kunt (2009) find that life and non-life insurance density increase with the income level of the country. However, the trend of life insurance coverage is more income-elastic than non-life insurance. Therefore, the inclusion of financial depth of a nation is an equally important consideration for research (see, inter alia, Enz 2000).

${ }^{6}$ Exceptions are Pradhan et al. 2014; Hassan et al. 2011; and Andersson et al. 2010 (see, Table 8 for more details).

${ }^{7}$ Both life and non-life insurance activities promote economic growth in their own way. This is because factors affecting life insurance activities are normally different from those of non-insurance activities (see, inter alia, Pan et al. 2012).

${ }^{8}$ The consideration of IMD over IMP is due to paucity of research in this area (see, inter alia, Park et al., 2002). Additionally, since we consider per capita gross domestic product as an indicator to economic growth while studying the Granger causality between the two (see details in Emperical strategy), the choice of insurance market density is a better combination in comparison to insurance market penetration.

${ }^{9}$ The trend of economic growth is not reported here due to space restrictions and can be made available on demand.

${ }^{10}$ It is considered as a percentage change of per capita gross domestic product.

${ }^{11}$ It includes LID, NID, and TID. The detailed discussion is available in Appendix C (see Table 9).

${ }^{12}$ All these variables were converted into their natural logarithms for estimation purposes.

${ }^{13}$ This includes the individual involvement of LID, NID, and TID separately (see Table 9).

${ }^{14}$ The inclusion of ECT in the regression model depends upon the presence of cointegration between insurance market density (LID/ NID/ TID) and economic growth. ECT needs to be removed in the estimation process, if the insurance market density and economic growth are not cointegrated.

${ }^{15}$ AIC stands for Akaike Information Criterion (Akaike, 1974).

${ }^{16}$ IMD involves the deployment of LID, NID, and TID, separately.

${ }^{17}$ ADF stands for Augmented Dickey Fuller test (Dickey and Fuller, 1981).

${ }^{18}$ LLC stands for Levine-Lin-Chu (Levine et al., 2002).

${ }^{19}$ We have three cases to observe the cointegration relationships between GDP and IMD, depending upon the deployment of three IMD indicators, namely LID, NID and TID. These three cases are: Case 1 - between GDP and LID; Case 2- between GDP and NID; and Case 3- between GDP and TID).

${ }^{20}$ It is used with the condition that both IMD and GDP are cointegrated. However, simple vector autoregressive model (VARM) is deployed for the absence of cointegration between the two.

${ }^{21}$ The availability of ECT is in the case of VECM only.

${ }^{22}$ The detailed discussion of these hypotheses are available in Pradhan et al. (2015a, 2015b).

${ }^{23}$ It includes both liquid liabilities (LIQ) and private credit by deposit money banks and other financial institutions (PCO).

${ }^{24}$ It is judged on the basis of the significance of error correction term.

${ }^{25}$ In the context of 10 OECD countries for the period 1979-2006.

${ }^{26}$ In the context of China for the period 2006-2011.

${ }^{27}$ In the context of G-20 countries for the period 1980-2011. 


\section{Appendix A: Review of Literature between Insurance Market Activities and Economic Growth}

Table 8 Summary of Studies on the Relationship between Insurance Market Activities and Economic Growth

\begin{tabular}{|c|c|c|c|}
\hline Research Reviews & Study Area & Time Period & Inferences \\
\hline Adams et al. (2009) & Sweden & 1830-1998 & SLH \\
\hline Akinlo (2013) & Nigeria & 1986-2010 & $\mathrm{NLH}$ \\
\hline Alhassan and Biekpe (2016) & 8 African countries & 1990-2010 & DFH, SLH, FBH \\
\hline Alhassan and Fiador (2014) & Ghana & 1990-2010 & SLH \\
\hline Arena (2008) & 56 countries & 1976-2004 & SLH \\
\hline Avram et al. (2010) & 93 countries & $1980-2006$ & SLH \\
\hline Beenstock et al. (1986) & 12 OECD countries & 1970-1981 & DFH \\
\hline Boon (2005) & Singapore & $1991-2002$ & SLH \\
\hline Catalan et al. (2000) & 14 OECD countries & 1975-1997 & DFH, SLH \\
\hline Chang et al. (2014) & 10 OECD countries & $1979-2006$ & $\mathrm{SLH}, \mathrm{DFH}, \mathrm{FBH}, \mathrm{NLH}$ \\
\hline Chau et al. (2013) & Malaysia & 1970-2002 & $\mathrm{NEH}$ \\
\hline Chen et al. (2012) & 60 countries & $1976-2005$ & SLH \\
\hline Ching et al. (2010) & Malaysia & 1997-2008 & DFH \\
\hline Esho et al. (2004) & 44 countries & 1984-1998 & DFH \\
\hline Ghosh (2013) & India & $1990-2008$ & SLH \\
\hline Guochen and Wei (2012) & China & 2006-2011 & $\mathrm{SLH}, \mathrm{DFH}, \mathrm{FBH}, \mathrm{NLH}$ \\
\hline Haiss and Sumegi (2008) & 29 European countries & 1992-2005 & SLH \\
\hline Han et al. (2010) & 77 countries & 1994-2005 & SLH \\
\hline Jahromi and Goudarzi (2014) & Iran & $1981-2011$ & $\mathrm{FBH}$ \\
\hline Kugler and Ofoghi (2005) & United Kingdom & $1966-2003$ & $\mathrm{DFH}, \mathrm{FBH}$ \\
\hline Lee et al. (2013a, 2013b) & 6 Developed countries & $1979-2007$ & SLH \\
\hline Lee (2011) & 10 OECD countries & 1979-2006 & SLH, DFH \\
\hline Pradhan et al. (2014) & G-20 countries & $1980-2012$ & $\mathrm{DFH}, \mathrm{FBH}$ \\
\hline Pradhan et al. (2015a, 2015b) & 34 OECD countries & $1980-2011$ & $\mathrm{SLH}, \mathrm{DFH}, \mathrm{FBH}, \mathrm{NLH}$ \\
\hline Ward and Zurbruegg (2000) & 9 OECD countries & 1961-1996 & DFH \\
\hline Webb et al. (2005a) & 55 countries & 1980-1996 & SLH \\
\hline
\end{tabular}

Note 1: SLH is supply-leading hypothesis, indicating unidirectional causality from insurance market to economic growth; $\mathrm{DFH}$ is demand-following hypothesis, indicating unidirectional causality from economic growth to insurance market; $\mathrm{FBH}$ is feedback hypothesis, indicating bidirectional causality between insurance market and economic growth; NLH is neutrality hypothesis, indicating absence of causality between insurance market and economic growth Note 2: OECD is Organization for Economic Cooperation and Development; and G-20 means the elite Group of 20 countries

\section{Appendix B: Brief Profile of Eurozone}

Historically, Eurozone was officially formed on first January, 1999 in order to extend the European Union's provisions on its internal market to countries in the European Free Trade Area. This group is also called the euro area, a monetary union of 19 of the 28 European Union (EU) member states which have adopted euro as their common currency. The other nine members of the European Union continue to use their own national currencies, although most of them are obliged to adopt euro in future. The aim of this group is to extend support to promote a 
continuous and balanced strengthening of trade and economic relations between the Eurozone member states, with similar conditions of competition and common rules in the internal market. The study chooses the sample of Eurozone countries to test the insurance-growth nexus. This sample has been chosen for the following reasons:

- First, the prevalence of common currency and hence, single member states cannot easily engineer a currency devaluation or any other financial strategy in order to stimulate economic growth (see, for instance, Baum et al. 2016). Hence, studying the linkage between insurance and economic growth in Eurozone countries more meaningful, as it is a homogenous cluster.

- Second, we focus on Eurozone because the countries must coordinate their economic, financial, and fiscal policies closely, much more so than other European Union (EU) member states (see, for instance, Baselga-Pascual et al. 2015; Bouheni and Hasnaoui 2017).

- Third, the insurance coverage is usually very high in Eurozone countries. It is approximately $35 \%$ of the total worldwide premium, which is the highest in the world followed by North America (30\%) and Asia (28\%).

- Fourth, the investment portfolio of insurance sector is also very high in Eurozone, which is equivalent to almost $€ 1117$ billion; also, the total benefits claimed are about $€ 952$ billion.

- Fifth, in Eurozone, some of the countries like France, Germany, the Netherlands, and Italy are considered as the biggest European markets for insurance (see, for instance, IES, 2014).

\section{Appendix C: Definition of Variables}

Table 9 Definition of Variables Relating to Insurance Markets and Economic Growth

\begin{tabular}{|c|c|}
\hline Variables & Definition \\
\hline LID & Life insurance ${ }^{28}$ density: It is the direct domestic life premiums per capita (in US Dollars). \\
\hline NID & Non-life insurance ${ }^{29}$ density: It is the direct domestic non-life premiums per capita (in US Dollars). \\
\hline TID & $\begin{array}{l}\text { Total insurance density: It is the direct domestic premiums, both life and non-life per capita (in US } \\
\text { Dollars). }\end{array}$ \\
\hline GDP & Economic growth: It is the per capita gross domestic product (in US Dollars). \\
\hline LIL & Liquid liabilities: It is the ratio of liquid liabilities (broad money supply) to gross domestic product. \\
\hline PCO & $\begin{array}{l}\text { Private credit: It is the private credit by deposit money banks and other financial institutions to } \\
\text { gross domestic product. }\end{array}$ \\
\hline GCE & $\begin{array}{l}\text { Government consumption expenditure: It is the government consumption expenditure as a } \\
\text { percentage of gross domestic product. }\end{array}$ \\
\hline YDP & $\begin{array}{l}\text { Young dependency population: It is the ratio of younger dependents-people younger than } \\
15 \text { years- to the working-age population. }\end{array}$ \\
\hline
\end{tabular}

Note: Insurance density means direct domestic premiums in USD (for life/ non-life/ total) per thousand population ${ }^{28}$ Life insurance is a form of insurance coverage that pays out premiums to the insured or their specified beneficiaries upon any incident (see, iter alia, Lee and Chiu 2012; Lee et al. 2012; Pan et al. 2012)

${ }^{29}$ Non-life insurance essentially consists of insurance policies that protect the insured against losses and damages other than those covered by life insurance such as property, motor, marine, transport, pecuniary loss, and aviation (see, iter alia, Chen et al. 2013; Lee et al. 2012; Pradhan et al. 2015a, 2015b) 


\section{Appendix D: Multivariate Analysis}

Table 10 Panel Unit Root Test Results

\begin{tabular}{|c|c|c|c|c|c|c|}
\hline \multirow[b]{3}{*}{ Variables } & \multicolumn{6}{|c|}{ Unit Root Test Statistics } \\
\hline & LLC & & & ADF & & \\
\hline & LD & FD & IN & LD & $\mathrm{FD}$ & IN \\
\hline LID & 5.88 & $-10.0^{*}$ & I [1] & 2.46 & $164.4^{*}$ & । [1] \\
\hline NID & 5.82 & $-11.4^{*}$ & । [1] & 2.64 & $188.5^{*}$ & । [1] \\
\hline TID & 6.77 & $-10.8^{*}$ & । [1] & 1.55 & $173.4^{*}$ & I [1] \\
\hline GDP & -0.30 & $-24.8^{*}$ & I [1] & 19.1 & $546.4^{*}$ & । [1] \\
\hline LIL & 4.93 & $-18.6^{*}$ & I [1] & 2.53 & $425.6^{*}$ & I [1] \\
\hline PCO & 3.59 & $-9.47^{*}$ & । [1] & 6.64 & $150.8^{*}$ & I [1] \\
\hline GCE & 0.97 & $-17.4^{*}$ & I [1] & 17.9 & $336.9^{*}$ & I [1] \\
\hline YDP & 0.81 & $-6.50^{*}$ & I [1] & 19.9 & $100.7^{*}$ & I [1] \\
\hline
\end{tabular}

Note 1: LID is life insurance density, NID is non-life insurance density, TID is total (both life and non-life) insurance density, GDP is per capita economic growth, LLL is liquidity liabilities; PCO is private credit by deposit money banks and other financial institutions, GCE is government consumption expenditure, and YDP is young dependence population

Note 2: LD stands for level data, FD stands for first difference data, LLC stands for Levine-Lin-Chu test (Levine et al. 2002), IPS stands for Im-Pesaran-Shin test (Im et al. 2003), and ADF stands for ADF-Fischer Chi-square test (Maddala and Wu 1999)

Note 3:* denotes significance at the $5 \%$ level

Note 4: I [1] stands for integrated of order one

Table 11 Panel Cointegration Test Results

\begin{tabular}{lll}
\hline Cases & Variables Included & Kao ADF Test \\
\hline Case 1.1 & GDP, LID, LIL, GCE, YDP & $-2.63[0.00]$ \\
Case 1.2 & GDP, LID, PCO, GCE, YDP & $-2.39[0.00]$ \\
Case 2.1 & GDP, NID, LIL, GCE, YDP & $-5.80[0.00]$ \\
Case 2.2 & GDP, NID, PCO, GCE, YDP & $-3.77[0.00]$ \\
Case 3.1 & GDP, TID, LIL, GCE, YDP & $-5.05[0.00]$ \\
Case 3.2 & GDP, TID, PCO, GCE, YDP & $-3.78[0.00]$ \\
\hline
\end{tabular}

Note 1: LID is life insurance density, NID is non-life insurance density, TID is total (both life and non-life) insurance

density, GDP is per capita economic growth, LIL is liquidity liabilities; PCO is private credit by deposit money banks and other financial institutions, GCE is government consumption expenditure, and YDP is young dependence population

Note 2: ADF is augmented Dickey Fuller statistics

Table 12 Granger Causality Test Results

\begin{tabular}{|c|c|c|c|c|c|c|}
\hline & \multicolumn{3}{|c|}{$\begin{array}{l}\text { Short Run Granger } \\
\text { Causality }\end{array}$} & \multicolumn{3}{|c|}{$\begin{array}{l}\text { Long Run Granger } \\
\text { Causality }\end{array}$} \\
\hline \multicolumn{7}{|c|}{ Case 1.1: VECM with GDP, LID, LIL, GCE, YDP } \\
\hline & $\triangle \mathrm{GDP}$ & $\Delta \mathrm{LID}$ & $\triangle G C E$ & $\triangle \mathrm{YDP}$ & $\Delta \mathrm{LIL}$ & $\mathrm{ECT}_{-1}$ \\
\hline$\triangle G D P$ & - & $9.78^{*}$ & $10.3^{*}$ & $18.3^{*}$ & 1.83 & $-0.85^{*}$ \\
\hline$\Delta L I D$ & 2.05 & - & $4.99^{*}$ & $3.98^{*}$ & 1.24 & -0.11 \\
\hline$\triangle \mathrm{GCE}$ & $12.9^{*}$ & 2.12 & - & $9.65^{*}$ & 1.79 & -0.06 \\
\hline$\triangle \mathrm{YDP}$ & 0.48 & 0.45 & $4.62^{*}$ & - & 1.79 & -0.001 \\
\hline$\Delta \mathrm{LIL}$ & $5.74^{*}$ & 1.80 & $4.82^{*}$ & $9.63^{*}$ & - & -0.09 \\
\hline \multicolumn{7}{|c|}{ Case 1.2: VECM with GDP, LID, PCO, GCE, YDP } \\
\hline & $\triangle \mathrm{GDP}$ & $\Delta L I D$ & $\triangle \mathrm{GCE}$ & $\triangle \mathrm{YDP}$ & $\triangle \mathrm{PCO}$ & $E C T_{-1}$ \\
\hline$\triangle G D P$ & - & $5.69^{*}$ & $13.1^{*}$ & $14.9^{*}$ & 0.20 & $-0.85^{*}$ \\
\hline$\Delta \mathrm{LID}$ & 2.09 & - & $3.71^{* *}$ & $9.54^{*}$ & $5.68^{*}$ & -0.09 \\
\hline$\triangle \mathrm{GCE}$ & $17.3^{*}$ & 1.86 & - & $9.89^{*}$ & 0.28 & -0.05 \\
\hline
\end{tabular}


Table 12 Granger Causality Test Results (Continued)

\begin{tabular}{|c|c|c|c|c|c|c|}
\hline$\triangle \mathrm{YDP}$ & 1.05 & 1.12 & $4.77^{*}$ & - & 1.37 & -0.001 \\
\hline$\triangle \mathrm{PCO}$ & $6.19^{*}$ & $5.69^{*}$ & 0.89 & 0.40 & - & -0.11 \\
\hline \multicolumn{7}{|c|}{ Case 2.1: VECM with GDP, NID, LIL, GCE, YDP } \\
\hline & $\triangle \mathrm{GDP}$ & $\Delta \mathrm{NID}$ & $\triangle \mathrm{GCE}$ & $\triangle \mathrm{YDP}$ & $\Delta \mathrm{LIL}$ & $E C T_{-1}$ \\
\hline$\triangle \mathrm{GDP}$ & - & 1.92 & $9.93^{*}$ & $17.4^{*}$ & 1.62 & $-0.79^{*}$ \\
\hline$\triangle N I D$ & $4.50^{*}$ & - & 1.05 & 1.57 & 0.15 & -0.18 \\
\hline$\triangle \mathrm{GCE}$ & $15.3^{*}$ & $9.75^{*}$ & - & $6.67^{*}$ & 2.15 & -0.06 \\
\hline$\triangle \mathrm{YDP}$ & 0.92 & $10.0^{*}$ & $4.78^{*}$ & - & 2.12 & -0.001 \\
\hline$\Delta \mathrm{LIL}$ & 2.09 & $3.09^{* * *}$ & $3.36^{* * *}$ & $8.57^{*}$ & - & -0.07 \\
\hline \multicolumn{7}{|c|}{ Case 2.2: VECM with GDP, NID, PCO, GCE, YDP } \\
\hline & $\triangle \mathrm{GDP}$ & $\Delta \mathrm{NID}$ & $\triangle G C E$ & $\triangle \mathrm{YDP}$ & $\triangle \mathrm{PCO}$ & $E C T_{-1}$ \\
\hline$\triangle \mathrm{GDP}$ & - & 1.30 & $12.5^{*}$ & $17.4^{*}$ & 0.47 & $-0.81^{*}$ \\
\hline$\triangle N I D$ & $6.53^{*}$ & - & 0.45 & $6.25^{*}$ & $4.02^{*}$ & -0.18 \\
\hline$\triangle \mathrm{GCE}$ & $17.8^{*}$ & $9.73^{*}$ & - & $7.75^{*}$ & 0.18 & -0.05 \\
\hline$\triangle \mathrm{YDP}$ & 2.33 & $9.23^{*}$ & $5.02^{*}$ & - & 0.81 & -0.002 \\
\hline$\triangle \mathrm{PCO}$ & 2.78 & $17.8^{*}$ & 0.15 & 0.37 & - & -0.09 \\
\hline \multicolumn{7}{|c|}{ Case 3.1: VECM with GDP, TID, LIL, GCE, YDP } \\
\hline & $\triangle \mathrm{GDP}$ & $\triangle T I D$ & $\triangle \mathrm{GCE}$ & $\triangle \mathrm{YDP}$ & $\Delta \mathrm{LIL}$ & $E C T_{-1}$ \\
\hline$\triangle \mathrm{GDP}$ & - & 2.26 & $10.6^{*}$ & $20.1^{*}$ & 1.99 & $-0.83^{*}$ \\
\hline$\triangle \mathrm{TID}$ & $3.69^{* *}$ & - & $4.25^{* *}$ & 2.54 & 0.62 & -0.17 \\
\hline$\triangle \mathrm{GCE}$ & $15.1^{*}$ & $6.96^{*}$ & - & $7.62^{*}$ & 2.44 & -0.06 \\
\hline$\triangle \mathrm{YDP}$ & 0.55 & $3.95^{* * *}$ & $4.79^{* *}$ & - & 1.74 & -0.001 \\
\hline$\Delta \mathrm{LIL}$ & $3.61^{* * *}$ & 0.16 & $3.88^{* * *}$ & $9.95^{*}$ & - & -0.08 \\
\hline \multicolumn{7}{|c|}{ Case 3.2: VECM with GDP, TID, PCO, GCE, YDP } \\
\hline & $\triangle \mathrm{GDP}$ & $\triangle T I D$ & $\triangle \mathrm{GCE}$ & $\triangle \mathrm{YDP}$ & $\triangle P C O$ & $\mathrm{ECT}_{-1}$ \\
\hline$\triangle \mathrm{GDP}$ & - & 1.09 & $13.6^{*}$ & $18.3^{*}$ & 0.37 & $-0.84^{*}$ \\
\hline$\triangle \mathrm{TID}$ & $6.16^{*}$ & - & 1.33 & $3.59^{* *}$ & $5.36^{*}$ & $-0.17^{*}$ \\
\hline$\triangle \mathrm{GCE}$ & $19.2^{*}$ & $5.83^{*}$ & - & $8.40^{*}$ & 0.11 & -0.06 \\
\hline$\triangle \mathrm{YDP}$ & 1.56 & $4.32^{* *}$ & $4.75^{*}$ & - & 1.09 & -0.001 \\
\hline$\triangle \mathrm{PCO}$ & $3.67^{* * *}$ & $15.9^{*}$ & 0.28 & 0.11 & - & -0.09 \\
\hline
\end{tabular}

Note 1: GDP is per capita economic growth, LID is life insurance density, NID is non-life insurance density, TID is total (both life and non-life) insurance density, LIL is liquidity liabilities; PCO is private credit by deposit money banks and other financial institutions, GCE is government consumption expenditure, and YDP is young dependence population. Note $2:{ }^{*}, * *$, and ${ }^{* * *}$ indicate statistical significance at $1 \%, 5 \%$, and $10 \%$ respectively.

Note 3: VECM: vector error-correction model; and $\mathrm{ECT}_{1}$ : lagged error-correction term.

Note 4: The values of ECT- ${ }_{1}$ are the estimated coefficients, while the remaining values against other variables are Wald Chi-square.

Note 5: The basis for determination of long-run causality lies in the significance of the lagged ECT coefficients.

Author details

${ }^{1}$ Vinod Gupta School of Management, Indian Institute of Technology, Kharagpur 721302, India. ${ }^{2}$ KL University, Andhra Pradesh 522502, India.

Received: 20 September 2016 Accepted: 2 September 2017

Published online: 23 September 2017

Acknowledgements

The authors thank the editor and reviewers of this journal for their insightful comments and suggestions, which has improved the quality of this paper.

\section{Funding}

This paper does not have any funding. 
Authors' contributions

All authors have equal contributions. All authors read and approved the final manuscript.

\section{Competing interests}

We declare that authors have no conflict of interest with respect to Funding Source Declaration, Author Agreement, and Permission Note for the submission paper "Insurance Market Density and Economic Growth in Eurozone Countries: The Granger Causality Approach" by Rudra P. Pradhan, Saurav Dash, Rana P. Maradana, Manju Jayakumar, and Kunal Gaurav to the possible inclusion in 'Financial Innovation'.

\section{Publisher's Note}

Springer Nature remains neutral with regard to jurisdictional claims in published maps and institutional affiliations.

\section{Author details}

${ }^{1}$ Vinod Gupta School of Management, Indian Institute of Technology, Kharagpur 721302, India. ${ }^{2}$ KL University, Andhra Pradesh 522502, India.

Received: 20 September 2016 Accepted: 2 September 2017

Published online: 23 September 2017

\section{References}

Adams M, Andersson J, Andersson L, Lindmark M (2009) Commercial banking, insurance and economic growth in Sweden between 1830 and 1998. Account Bus Financ Hist 19(1):21-38

Akaike H (1974) A new look at the statistical model identification. IEEE Trans Autom Control 19(6):716-723

Akinlo T (2013) The causal relationship between insurance and economic growth in Nigeria (1986-2010). Aust J Bus Manag Res 2(12):49-57

Alhassan AL, Biekpe N (2016) Insurance market development and economic growth. Int J Soc Econ 43(3):321-339

Alhassan AL, Fiador V (2014) Insurance-growth nexus in Ghana: an autoregressive distributed lag bounds Cointegration approach. Rev Dev Finance 4(2):83-96

Altunbas Y, Thornton J (2013) Deposit insurance and private capital inflows: further evidence. J Int Financ Mark Inst Money 27:243-247

Andersson LA, Eriksson L, Lindmark M (2010) Life insurance and income growth: the case of Sweden 1830-1950. Scand Econ Hist Rev 58(3):203-219

Arena M (2006) Does Insurance Market Activity Promote Economic Growth? Country Study for Industrial and Developing Countries, Policy Research Working Paper Series, No. 4098. The World Bank, Washington DC

Arena M (2008) Does insurance market activity promote economic growth? A cross-country study for industrialized and developing countries. J Risk Insur 75(4):921-946

Avram K, Nguyen Y, Skully M (2010) Insurance and Economic Growth: a Cross Country Examination. Working Paper. Australian Centre for Financial Studies-Finsia Banking and Finance Conference, Australia

Azman-Saini WNW, Smith P (2011) Finance and growth: new evidence on the role of insurance. S Afr J Econ 79(2):111-127

Baselga-Pascual L, Trujillo-Ponce A, Cardone-Riportella C (2015) Factors influencing Bank risk in Europe: evidence from the financial crisis. North Am J Econ Finance 34:138-166

Baum CF, Schafer D, Stephan A (2016) Credit rating agency downgrades and the Eurozone sovereign debt crises. J Financ Stab 24:117-131

Beck T, Demirguc-Kunt A (2009) Financial institutions and markets across countries and over time - data and analysis. The World Bank, Washington DC

Beck T, Levine R (2004) Stock markets, banks, and growth: panel evidence. J Bank Finance 28(3):423-442

Beck T, Webb I (2003) Economic, demographic, and institutional determinants of life insurance consumption across countries. World Bank Econ Rev 17(1):51-88

Beenstock M, Dickinson G, Khajuria S (1986) The determination of life premiums: an international cross-section analysis 1970-1981. Insur Math Econ 5(1):616-634

Billio M, Getmansky M, Lo AW, Pelizzon L (2012) Econometric measures of connectedness and systemic risk in the finance and insurance sectors. J Financ Econ 104(3):535-559

Boon TK (2005) Do commercial banks, stock markets and insurance market promote economic growth? An analysis of the Singapore economy. Working Paper, Nanyang Technological University, Singapore

Bouheni, F. B. and Hasnaoui, A. (2017). Cyclical behavior of the financial stability of Eurozone commercial banks. Econ Model (forthcoming)

Brainard L (2008) What is the role of Insurance in Economic Development? Zurich government and industry affairs thought leadership series paper. No 2:1-13

Caporale GM, Howells PG, Soliman AM (2004) Stock market development and economic growth: the causal linkage. J Econ Dev 29(1):33-50

Catalan M, Impavido G, Musalem AR (2000) Contractual savings or stock market development- which leads? Unpublished policy research working paper, No. 2421. The World Bank, Washington DC

Chang C, Lee C (2012) Non-linearity between life insurance and economic development: a revisited approach. Geneva Risk Insur Rev 37(2):223-257

Chang T, Cheng SC, Pan G, Wu TP (2013) Does globalization affect the insurance markets? Bootstrap panel granger causality test. Econ Model 33(1):254-260

Chang T, Lee CC, Chang CH (2014) Does insurance activity promote economic growth? Further evidence based on bootstrap panel granger causality test. Eur J Finance 20(12):1187-1210

Chau WH, Khin AA, Teng KLL (2013) Economic development Cointegration and Malaysian life and general insurance consumption. Aust J Basic Appl Sci 7(10):538-546 
Chen PF, Lee CC, Lee CF (2012) How does the development of life insurance market affect economic growth? Some international evidence. J Int Dev 24(7):865-893

Chen SS, Cheng SC, Pan G, Wu TP (2013) The relationship between globalization and insurance activities: a panel data analysis. Jpn World Econ 28(3):151-157

Ching KSC, Kogid M, Furuoka F (2010) Causal relation between life insurance funds and economic growth: evidence from Malaysia. ASEAN Econ Bull 27(2):185-199

Cristea M, Marcu N, Carstina S (2014) The relationship between insurance and economic growth in Romania compared to the main results in Europe- a theoretical and empirical analysis. Procedia- Econ Finance 8:226-235

Dickey DA, Fuller WA (1981) Likelihood ratio statistics for autoregressive time series with a unit root. Econometrica 49(4):1057-1072

Enz R (2000) The S-curve relation between per-capita income and insurance penetration. Geneva Pap Risk Insur 25(3):396-406

Esho N, Kirievsky A, Ward D, Zurbruegg R (2004) Law and the Determinants of Property-Causality Insurance. Journal of Risk and Insurance 71(2):265-283

Garcia MTM (2012) Determinants of the property-liability insurance market: evidence from Portugal. J Econ Stud 39(4):2012

Ghosh A (2013) Does life insurance activity promote economic development in India: an empirical analysis? J Asia Bus Stud 7(1):31-43

Granger CWJ (1988) Some Recent Developments in a Concept of Causality. Journal of Econometrics 39(1-2):199-211

Guo F, Huang YS (2013) Identifying permanent and transitory risks in the Chinese property insurance market. North Am J Econ Finance 26(3):689-704

Guochen P, Wei SC (2012) The relationship between insurance development and economic growth: a cross-region study for China. In: Paper presented at 2012 China international conference on insurance and risk management, held at Qingdao, during July 18-21, 2012

Haiss PR, Sumegi K (2008) The relationship between insurance and economic growth in Europe: a theoretical and empirical analysis. Empirica 35(4):405-431

Han L, Li D, Moshirian F, Tian L (2010) Insurance development and economic growth. Geneva Pap Risk Insur 35(2):183-199

Hassan KM, Sanchez B, Yu J (2011) Financial development and economic growth: new evidence from panel data. Q Rev Econ Finance 51(1):88-104

Hussels S, Ward D, Zurbruegg R (2005) Stimulating the demand for insurance. Risk Manag Insur Rev 8(2):257-278

IES (2014) Insurance Europe statistics. Insurance Europe aisbl, Brussels

Im KS, Pesaran MH, Shin Y (2003) Testing for Unit Roots in Heterogeneous Panels. Journal of Econometrics 115(1):53-74

Jahromi PB, Goudarzi H (2014) The study of Cointegration and causal relationship between macroeconomic variables and insurance penetration ratio. Asian Econ Financial Rev 4(7):853-863

Johansen S (1988) Statistical analysis of Cointegration vectors. J Econ Dyn Control 12(2-3):231-254

Kar M, Nazlioglu S, Agir H (2011) Financial development and economic growth nexus in the MENA countries: bootstrap panel granger causality analysis. Econ Model 28(1-2):685-693

King R, Levine R (1993) Finance and growth: Schumpeter might be right. Q J Econ 108(3):717-737

Kugler M, Ofoghi R (2005) Does Insurance Promote Economic Growth? Evidence from the UK. Paper presented at the Money Macro and Finance (MMF) Research Group Conference, UK

Lee C, Huang W, Yin C (2013b) The dynamic interactions among the stock, bond and insurance markets. North Am J Econ Finance 26(3):28-52

Lee CC (2011) Does insurance matter for growth: empirical evidence from OECD countries. B E J Macroeconomics 11(1):1-26

Lee CC, Chiu YB (2012) The impact of real income on insurance penetration: evidence from panel data. Int Rev Econ Financ 21(1):246-260

Lee CC, Chang CP, Chen PF (2012) Further evidence on property-casualty insurance premiums: do multiple breaks and country characteristics matter? Jpn World Econ 24(3):215-226

Lee CC, Tsong CC, Yang SJ, Chang CH (2013a) Investigating the Stationarity of insurance premiums: international evidence. Eur J Finance 19(4):276-297

Levine A, Lin CF, Chu CSJ (2002) Unit root tests in panel data: asymptotic and finite-sample properties. J Econ 108(1):1-24

Levine R (1999) Financial Development and Economic Growth: Views and Agenda, World Back Policy Research Working Paper, No. 178. World Bank, Washington DC

Levine R, Zervos S (1998) Stock markets, banks and economic growth. Am Econ Rev 88(3):537-558

Levine R, Loayza N, Beck T (2000) Financial intermediation and growth: causality analysis and causes. J Monet Econ 46(1):31-77

Li D, Moshirian F, Nguyen P, Wee T (2007) The demand for life insurance in OECD countries. Journal of Risk and Insurance 74(3):637-652

Liu G, He L, Yue Y, Wang J (2014) The linkage between insurance activity and banking credit: some evidence from dynamics analysis. North Am J Econ Finance 29(3):239-265

Liu GC, Lee CC (2014) Insurance activities and banking credit causal nexus: evidence from China. Appl Econ Lett 21(9):626-630

Maddala GS, Wu S (1999) A comparative study of unit root tests with panel data and new sample test. Oxf Bull Econ Stat 61(S1):631-652

Moshirian F (1999) Sources of growth in international insurance services. J Multinational Financial Manag 9:177-194

Nejad HR, Kermani SA (2012) The relation between insurance development and economic growth in Iran. Finance Manag 47:9079-9087

Nektarios M (2010) A growth theory for the insurance industry. Risk Manag Insur Rev 13(1):45-60

Outreville FJ (1990) The economic significance of Insurance Markets in Developing Countries. J Risk Insur 57(3):487-498

Outreville FJ (1996) Life Insurance Markets in Developing Countries. J Risk Insur 63(2):263-278

Outreville FJ (2013) The relationship between insurance and economic development: 85 empirical papers for a review of the literature. Risk Manag Insur Rev 16(1):71-122

Pan G, Chang H, Su C (2012) Regional differences in development of life Insurance Markets in China. Emerg Mark Rev 13(4):548-558

Park H, Borde SF, Choi Y (2002) Determinants of insurance pervasiveness: a cross-national analysis. Int Bus Rev 11:79-96 
Pegkas P (2015) The impact of FDI on economic growth in Eurozone countries. J Econ Asymmetries 12:124-132 Pesaran MH (2004) General Diagnostic Tests for Cross Section Dependence in Panels, Cambridge Working Paper in Economics, No. 0435. University of Cambridge, Cambridge

Petkovski M, Jordan C (2014) An analysis of non-life insurance determinants for selected countries in central and South Eastern Europe: a co-integration approach. Rom J Econ Forecasting 17(3):160-178

Pradhan RP, Bahmani S, Kiran MU (2014) The dynamics of insurance sector development, banking sector development and economic growth: Evidence from G-20 countries. Global Economics and Management Review 19(1):16-25

Pradhan RP, Kiran MU, Dash S, Chatterjee D, Zaki DB, Maradana R (2015a) Development of insurance sector and economic growth: the G-20 experience. South Asian J Manag 22(1):73-96

Pradhan RP, Arvin MB, Norman NR (2015b) Insurance development and the finance- growth nexus: evidence from 34 OECD countries. J Multinational Financial Manag 31:1-22

Pradhan RP, Arvin MB, Bahmani S, Bennett SE, Hall JH (2017) Insurance-Growth Nexus and Macroeconomic Determinants: Evidence from Middle-income Countries. Empirical Economics 52(4):1337-1366

Skipper HD, Kwon WJ (2007) Risk management and insurance: perspectives in a global economy. Blackwell Publishing, Oxford

Soo HH (1996) Life insurance and economic growth: theoretical and empirical investigation. Doctoral Dissertation, University of Nebraska, Lincoln

Ward D, Zurbruegg R (2000) Does insurance promote economic growth? Evidence from OECD countries. J Risk Insur 67(4):489-506

Wasow B, Hill RD (1986) Determinants of insurance penetration: a cross-country analysis. In: B. Wasow B, Hill RD (eds) Insurance industry in economic development. New York University Press, New York, pp 160-176

Webb IP, Grace MF, Skipper HD (2005a) The effect of banking and insurance on the growth of capital and output. SBS Revista De TermasFinancieros 2(2):1-32

Webb IP, Grace MF, Skpper HD (2005b) The Effect of Banking and Insurance on the Growth of Capital and Output. SBS Revista De Termas Financieros 2(2):1-32

Submit your manuscript to a SpringerOpen ${ }^{\circ}$ journal and benefit from:

- Convenient online submission

- Rigorous peer review

Open access: articles freely available online

- High visibility within the field

- Retaining the copyright to your article

Submit your next manuscript at $>$ springeropen.com 